\title{
Analisis K-Medoids Dalam Pengelompokkan Penduduk Buta Huruf Menurut Provinsi
}

\author{
Sri Rahayu Ningsih' ${ }^{1}$ Irfan Sudahri Damanik², Agus Perdana Windarto ${ }^{3}$, Heru Satria \\ Tambunan ${ }^{4}$, Jalaluddin ${ }^{5}$, Anjar Wanto ${ }^{6}$ \\ STIKOM Tunas Bangsa Pematangsiantar \\ Jl. Jenderal Sudirman Blok A No.1-3 Pematangsiantar, Indonesia \\ srirahayuningsih1310@gmail.com
}

\begin{abstract}
Illiteracy is the state of being unable to read and to write for communication. A large number of people still experiencing illiteracy in a country is one indicator showing that the country is still not developed. As many as 3.4 million people or around 2.07\% of the population in Indonesia are still illiterate. This study aims to create a grouping model using the $k$-medoids algorithm. The $k$ medoids method is a clustering method that serves to break down datasets into groups. The data used is sourced from the Central Statistics Agency. Entered data are percentage of illiterate population in 2009-2017. The number of records used is 34 provinces which are divided into 3 clusters namely high cluser, medium cluster and low cluster. From the results of k-medoids calculation, one (1) province was categorited as a high cluster, twelve (12) provinces as a medium cluster and twenty-one (21) provinces as a low cluster. The implementation process using the RapidMiner 5.3 application is used to help find accurate values. It is hoped that this research can be used as one of the bases for decision making for the government in an effort to equalize the level of illiteracy according to the province which has an impact on reducing of illiteracy rates in Indonesia.
\end{abstract}

Keywords: Data mining, Clustering, K-Medoids, Illiteracy, RapidMiner 5.3.

Abstrak- Buta huruf adalah seseorang yang tidak dapat membaca dan tidak dapat menulis untuk modal berkomunikasi. Banyaknya angka jumlah jiwa yang masih mengalami buta huruf di suatu negara merupakan salah satu indikator yang menunjukkan negara tersebut masih belum maju. sebanyak 3,4 juta jiwa atau sekitar 2,07\% penduduk di indonesia masih mengalami buta huruf dari total seluruh penduduk Indonesia. Penelitian ini bertujuan untuk membuat sebuah model pengelompokkan menggunakan algoritma $k$-medoids. Metode $k$-medoids merupakan metode clustering yang berfungsi untuk memecah dataset menjadi kelompok-kelompok. Data yang digunakan bersumber dari Badan Pusat Statistik. Data masukkan adalah presentase penduduk buta huruf tahun 2009-2017. Jumlah record yang digunakan sebanyak 34 provinsi yang dibagi kedalam 3 cluster yakni cluser tinggi, cluster sedang dan cluster rendah. Dari hasil perhiungan $k$-medoids diperoleh sebanyak 1 provinsi sebagai cluster tinggi, 12 provinsi sebagai cluster sedang dan 21 provinsi sebagai cluser rendah. Proses implementasi menggunakan aplikasi RapidMiner 5.3 digunakan untuk membantu menemukan nilai yang akurat. Diharapkan penelitian ini dapat digunakan sebagai salah satu dasar pengambilan keputusan kepada pihak pemerintah dalam upaya pemerataan tingkat buta huruf menurut provinsi yang berdampak menurunkan angka buta huruf di indonesia.

Kata kunci: Data mining, Clustering, K-Medoids, Buta Huruf, RapidMiner 5.3

\section{PENDAHULUAN}

Buta huruf adalah seseorang yang tidak dapat membaca dan tidak dapat menulis untuk modal berkomunikasi. Banyaknya angka jumlah jiwa yang masih mengalami buta huruf di suatu negara merupakan salah satu indikator yang menunjukkan negara tersebut masih belum maju. Buta huruf berkaitan dengan pendidikan yang menjadi salah satu indikator kemajuan sebuah bangsa. Pendidikan adalah pembelajaran, keterampilan, dan kebiasaan sekelompok orang 
yang diturunkan dari satu generasi ke generasi berikutnya melalui pengajaran, pelatihan atau penelitian. Badan Pusat Statistik (BPS) mendata sebanyak 3,4 juta jiwa atau sekitar 2,07\% penduduk di indonesia masih mengalami buta huruf dari total seluruh penduduk Indonesia. Pada kenyataannya, buta huruf telah mendorong di belakang lebih dari 700 juta orang dalam perlombaan kemajuan dan pembangunan. Banyak negara di belahan dunia yang masih memiliki angka buta huruf cukup tinggi. Berdasarkan data UNISCO 2015 terdapat 10 negara yang harus bekerja keras dalam menstabilkan tingkat buta huruf. Berikut ini adalah grafik buta huruf di dunia dapat dilihat pada gambar berikut.

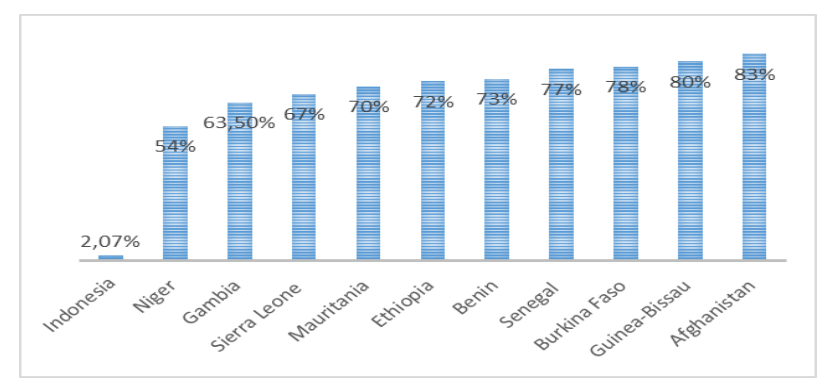

Gambar 1. Presentase Buta Huruf di Dunia

Dari gambar 1. menjelaskan bahwa hampir dari seluruh belahan negara memiliki angka buta huruf tingkat tinggi. Dampak ini mengakibatkan negara tersebut tidak dapat bersaing di masa yang akan datang. Hal ini menjadi persoalan hampir di semua negara karena terkait dengan kemiskinan, keterbelakangan, kebodohan, dan ketidakberdayaan masyarakat. Banyak perusahaan/investor asing yang menanamkan modal khususnya ke indonesia tetapi bukan orang indonesia yang menjadi pekerja utamanya, hal ini berdampak pula pada tingkat pengangguran di indonesia. Seiring perkembangan zaman hal ini butuh penanganan serius oleh pemerintah dalam mengurangi peningkatan buta huruf di indonesia dan menghindari persentase buta huruf tingkat tinggi seperti negara-negara lain di masa yang akan datang.

Banyak cabang ilmu komputer dapat memecahkan masalah yang kompleks, salah satunya data mining. Data mining merupakan teknik pengolahan data dalam jumlah besar untuk pengelompokan [1]. Beberapa penelitian di bidang data mining oleh [2] dalam penelitiannya data mining digunakan pada beras impor menurut negara asal untuk membuat penilaian impor beras dengan menerapkan algoritma $k$-means clustering. [3]implimentasi data mining menggunakan algoritma $k$-means clustering dapat memberikan informasi dalam upaya menstabilkan tanaman pangan kepada pemerintah pada pengelompokan tanaman padi berdasarkan provinsi di indonesia.

Data mining biasanya digunakan untuk memperbaiki pengambilan keputusan di masa yang akan datang berdasarkan informasi yang diperoleh dari masa lalu. Misalnya untuk prediksi, estimasi, assosiasi, clustering, dan deskripsi [4] Salah satu algoritma clustering adalah $k$-medoids. Algoritma $k$-medoids merupakan algoritma clustering yang berfungsi untuk memecah dataset menjadi kelompok-kelompok. Kelebihan dari algoritma ini mampu mengatasi kelemahan dari algoritma $k$-means 
yang sensitive terhadap outlier [5]. Untuk mengetahui tingkat buta huruf suatu provinsi di indonesia penulis menggunakan teknik data mining dalam proses pengolahan data dengan algoritma $k$-medoids. Data yang telah didapatkan selanjutnya dikelompokkan kedalam cluster dan diuji menggunakan RapidMiner 5.3 pada pengelompokkan persentase penduduk buta huruf dari 34 provinsi di indonesia. Berdasarkan permasalahan diatas, maka penulis mengangkat judul "Analisis K-Medoids Dalam Pengelompokkan Penduduk Buta Huruf Menurut Provinsi". Diharapkan dengan adanya penelitian ini dapat digunakan sebagai salah satu dasar pengambilan keputusan kepada pihak pemerintah dalam upaya pemerataan tingkat buta huruf menurut provinsi yang berdampak menurunkan angka buta huruf di indonesia melalui kegiatan sosialisasi dan penanganan fasilitas pendidikan dalam menunjang kemajuan di indonesia.

\section{METODOLOGI PENELITIAN}

Penelitian ini dilakukan untuk mengimplementasikan data mining khususnya algoritma $k$-medoids dalam menemukan cluster tingkat rendah, sedang, dan tinggi atau mengetahui sejauh mana tingkat buta huruf di indonesia.

\subsection{Analisa Data}

Proses analisa data dilakukan setelah adanya pengumpulan dan bukti yang mendukung penelitian. Dalam melakukan penelitian ini data yang digunakan penulis untuk mendukung terlaksananya penelitian ini merupakan data sekunder yang bersumber dari Badan Pusat Statistik (BPS) dengan subjek data (2009-2017). Kemudian data diolah dengan RapidMiner 5.3. untuk mencari keakuratan data.

Tabel 1. Data Penelitian

\begin{tabular}{|l|c|c|c|c|c|c|c|c|c|}
\hline \multirow{2}{*}{ Provinsi } & \multicolumn{9}{|c|}{ Persentase Penduduk yang Buta Huruf (Laki-laki + Perempuan) } \\
\cline { 2 - 11 } & $\mathbf{2 0 0 9}$ & $\mathbf{2 0 1 0}$ & $\mathbf{2 0 1 1}$ & $\mathbf{2 0 1 2}$ & $\mathbf{2 0 1 3}$ & $\mathbf{2 0 1 4}$ & $\mathbf{2 0 1 5}$ & $\mathbf{2 0 1 6}$ & $\mathbf{2 0 1 7}$ \\
\hline Aceh & 3.13 & 2.74 & 3.66 & 3.38 & 2.98 & 2.28 & 2.09 & 2.26 & 1.85 \\
\hline Sumatera Utara & 2.47 & 2.40 & 2.85 & 2.36 & 1.95 & 1.31 & 1.18 & 1.12 & 1.04 \\
\hline Sumatera Barat & 2.79 & 2.60 & 3.41 & 2.97 & 2.37 & 1.47 & 1.29 & 1.19 & 1.07 \\
\hline Riau & 1.69 & 1.49 & 2.19 & 2.01 & 1.93 & 1.16 & 1.06 & 0.93 & 0.79 \\
\hline Jambi & 3.93 & 3.67 & 3.99 & 3.57 & 2.91 & 1.99 & 1.92 & 1.99 & 1.72 \\
\hline Sumatera Selatan & 2.47 & 2.34 & 3 & 2.81 & 2.51 & 1.71 & 1.58 & 1.54 & 1.35 \\
\hline Bengkulu & 4.46 & 4.15 & 4.32 & 3.80 & 3.18 & 2.27 & 2.10 & 2.25 & 1.96 \\
\hline Lampung & 4.95 & 4.75 & 4.44 & 4.35 & 3.78 & 3.12 & 2.98 & 3.22 & 2.79 \\
\hline Kep. Bangka & 4.13 & 4.12 & 3.98 & 3.73 & 3.27 & 2.16 & 2.11 & 2.34 & 2.03 \\
Belitung & & & & & & & & & \\
\hline Kep. Riau & 3.54 & 2.51 & 2.16 & 2.01 & 1.90 & 1.23 & 1.08 & 1.16 & 1.12 \\
\hline Dki Jakarta & 0.99 & 0.81 & 1.10 & 0.86 & 0.82 & 0.43 & 0.39 & 0.36 & 0.32 \\
\hline Jawa Barat & 3.56 & 3.38 & 3.62 & 3.39 & 2.95 & 1.84 & 1.78 & 1.78 & 1.62 \\
\hline Jawa Tengah & 9.36 & 8.98 & 8.58 & 8.45 & 7.82 & 6.27 & 6.18 & 6.70 & 6.01 \\
\hline Di Yogyakarta & 9.02 & 8.38 & 7.76 & 7.30 & 6.62 & 5.12 & 5.05 & 5.41 & 4.91 \\
\hline Jawa Timur & 10.99 & 10.53 & 10.32 & 9.65 & 8.88 & 7.77 & 7.70 & 8.41 & 7.47 \\
\hline Banten & 3.56 & 3.40 & 3.35 & 3.07 & 3.05 & 2.51 & 2.33 & 2.45 & 2.21 \\
\hline Bali & 11.52 & 10.51 & 9.73 & 8.81 & 8.28 & 6.70 & 6.52 & 7.18 & 6.41 \\
\hline Nusa Tenggara & 17.20 & 16.51 & 14.56 & 14.14 & 13.34 & 11.36 & 11.34 & 12.94 & 11.47 \\
Barat & & & & & & & & & \\
\hline Nusa Tenggara & 10.34 & 9.84 & 10.80 & 9.70 & 8.37 & 7.62 & 7.27 & 8.48 & 7.25 \\
\hline
\end{tabular}




\begin{tabular}{|l|c|c|c|c|c|c|c|c|c|}
\hline \multirow{2}{*}{ Provinsi } & \multicolumn{9}{|c|}{ Persentase Penduduk yang Buta Huruf (Laki-laki + Perempuan) } \\
\cline { 2 - 11 } & $\mathbf{2 0 0 9}$ & $\mathbf{2 0 1 0}$ & $\mathbf{2 0 1 1}$ & $\mathbf{2 0 1 2}$ & $\mathbf{2 0 1 3}$ & $\mathbf{2 0 1 4}$ & $\mathbf{2 0 1 5}$ & $\mathbf{2 0 1 6}$ & $\mathbf{2 0 1 7}$ \\
\hline Timur & & & & & & & & & \\
\hline Kalimantan Barat & 9.06 & 8.57 & 8.76 & 7.79 & 7.69 & 6.79 & 6.71 & 7.61 & 6.75 \\
\hline $\begin{array}{l}\text { Kalimantan } \\
\text { Tengah }\end{array}$ & 2.32 & 2.22 & 2.83 & 2.25 & 1.88 & 1.10 & 0.99 & 1.03 & 0.92 \\
\hline Kalimantan Selatan & 4.10 & 3.66 & 3.87 & 3.18 & 2.66 & 1.65 & 1.61 & 1.72 & 1.48 \\
\hline Kalimantan Timur & 2.82 & 2.64 & 2.74 & 2.19 & 2.26 & 1.33 & 1.18 & 1.18 & 0.96 \\
\hline Kalimantan Utara & 0 & 0 & 0 & 0 & 0 & 0 & 4.31 & 4.95 & 4.37 \\
\hline Sulawesi Utara & 0.73 & 0.65 & 1.09 & 1.10 & 0.89 & 0.41 & 0.34 & 0.21 & 0.27 \\
\hline Sulawesi Tengah & 3.75 & 3.50 & 5.03 & 4.58 & 3.71 & 2.76 & 2.40 & 2.49 & 2.17 \\
\hline Sulawesi Selatan & 11.33 & 10.84 & 10.52 & 9.90 & 8.68 & 7.73 & 7.67 & 8.48 & 7.47 \\
\hline Sulawesi Tenggara & 7.34 & 7.10 & 7.59 & 7.38 & 6.44 & 5.24 & 5.09 & 5.75 & 4.95 \\
\hline Gorontalo & 3.82 & 3.61 & 4.75 & 4.33 & 3.07 & 2.08 & 1.62 & 1.56 & 1.53 \\
\hline Sulawesi Barat & 10.81 & 10.09 & 11.01 & 9.69 & 8.07 & 6.83 & 6.25 & 7.25 & 6.29 \\
\hline Maluku & 2.23 & 2.21 & 3.06 & 2.62 & 1.98 & 1.12 & 1.01 & 1.06 & 0.81 \\
\hline Maluku Utara & 3.78 & 3.48 & 3.65 & 3.12 & 2.34 & 1.54 & 1.39 & 1.33 & 1.22 \\
\hline Papua Barat & 6.40 & 4.41 & 6.99 & 4.80 & 4.31 & 3.37 & 2.83 & 2.95 & 2.62 \\
\hline Papua & 27.77 & 29.59 & 33.82 & 31.76 & 30.87 & 27.35 & 26.81 & 28.98 & 24.20 \\
\hline
\end{tabular}

\subsection{Data Mining}

Data mining merupakan serangkaian proses untuk menggali nilai tambah berupa informasi yang selama ini tidak diketahui secara manual dari suatu basis data. Data mining mulai ada sejak 1990-an sebagai cara yang benar dan tepat untuk mengambil pola dan informasi yang digunakan untuk menemukan hubungan antara data untuk melakukan pengelompokkan ke dalam satu atau lebih cluster sehingga objek - objek yang berada dalam satu cluster akan mempunyai kesamaan yang tinggi antara satu dengan lainnya. Data mining merupakan bagian dari proses penemuan pengetahuan dari basis data Knowledge Discovery in [6].

\subsection{Algoritma K-Medoids}

Menurut [7] "Algoritma $k$-medoids adalah algoritma pengelompokkan yang berkaitan dengan algoritma $k$-means dan algoritma medoidshift". Algoritma $k$ medoids dikembangkan oleh Leonard Kaufman dan Peter J. Rousseeuw pada tahun 1987. Algoritma $k$-medoids sering disebut juga algoritma Partitoning Around Medoids (PAM). Algoritma $k$-medoids memiliki kesamaan dengan algoritma $k$ means yaitu sama-sama termasuk algoritma partitioning. Algoritma partitioning merupakan algoritma pengelompokan data ke dalam sejumlah cluster tanpa adanya struktur hirarki antara satu dengan yang lainnya. Algoritma $k$-medoids memiliki keunggulan dibandingkan dengan algoritma $k$-means. K-medoids memiliki kinerja yang lebih optimal jika jumlah data yang digunakan berjumlah sedikit. Algoritma ini menggunakan objek pada kumpulan objek untuk mewakili sebuah cluster. Objek yang terpilih untuk mewakili sebuah cluster disebut medoids [8]. Beberapa langkah-langkah dalam perhitungan algoritma $k$-medoids adalah:

a. Inisialisasi pusat cluster sebanyak $k$ (jumlah cluster)

b. Alokasikan setiap data (objek) ke cluster terdekat menggunakan persamaan ukuran jarak Euclidian Distance dengan persamaan: 


$$
d_{i j}=\sqrt{\left.\sum_{a=1}^{p}\left(x_{i \alpha}-x_{j \alpha}\right)^{2}=\sqrt{\left(x_{i}\right.}-x_{j}\right)^{d}\left(x_{i}-x_{j}\right)}
$$

dimana $i=1, \ldots . ., n ; j=1, \ldots . ., n$ dan $p$ adalah banyak variable, serta $V$ adalah matrik varian kovarian.

c. Pilih secara acak objek pada masing-masing cluster sebagai kandidat medoids baru.

d. Hitung jarak setiap objek yang berada pada masing-masing cluster dengan kandidat medoids baru.

e. Hitung total simpangan $(S)$ dengan menghitung nilai total distance baru - total distance lama. Jika $S<0$, maka tukar objek dengan data cluster untuk membentuk sekumpulan $k$ objek baru sebagai medoids.

f. Ulangi langkah 3 sampai 5 hingga tidak terjadi perubahan medoids, sehingga didapatkan cluster beserta anggota cluster masing-masing.

\section{HASIL DAN PEMBAHASAN}

Pada penelitian ini digunakan aplikasi RapidMiner 5.3. sebagai pengujian data yang di analisa. Berikut merupakan penjelaskan implementasi $k$-medoids pada data penduduk buta huruf di indonesia.

Bebarapa tahapan dalam proses perhitungan manual menggunakan algoritma $k$-medoids pada penduduk buta huruf di indonesia adalah sebagai berikut :

Menentukan jumlah cluster $(k)$ dari $n$ objek adalah 3 cluster.

a. Mengasumsikan centroid awal yang telah ditentukan seperti pada tabel 2 .

Tabel 2. Medoids

\begin{tabular}{|c|l|c|c|c|c|c|c|c|c|c|}
\hline Nama & Provinsi & $\mathbf{2 0 0 9}$ & $\mathbf{2 0 1 0}$ & $\mathbf{2 0 1 1}$ & $\mathbf{2 0 1 2}$ & $\mathbf{2 0 1 3}$ & $\mathbf{2 0 1 4}$ & $\mathbf{2 0 1 5}$ & $\mathbf{2 0 1 6}$ & $\mathbf{2 0 1 7}$ \\
\hline C1 & $\begin{array}{l}\text { Sulawesi } \\
\text { Tengah }\end{array}$ & 3,75 & 3,50 & 5,03 & 4,58 & 3,71 & 2,76 & 2,40 & 2,49 & 2,17 \\
\hline C2 & $\begin{array}{l}\text { Sulawesi } \\
\text { Selatan }\end{array}$ & 11,33 & 10,84 & 10,52 & 9,90 & 8,68 & 7,73 & 7,67 & 8,48 & 7,47 \\
\hline C3 & $\begin{array}{l}\text { Sulawesi } \\
\text { Tenggara }\end{array}$ & 7,34 & 7,10 & 7,59 & 7,38 & 6,44 & 5,24 & 5,09 & 5,75 & 4,95 \\
\hline
\end{tabular}

b. Menempatkan objek-objek non medoids ke dalam cluster yang paling dekat dengan medoids berdasarkan jarak Euclidean. Berikut adalah perhitungan jarak pada data buta huruf :

$$
\begin{aligned}
& d_{\text {Aceh }, 11}=\sqrt{\begin{array}{l}
(3,13-3,75)^{2}+(2,74-3,50)^{2}+(3,66-5,03)^{2} \\
+(3,38-4,58)^{2}+(2,98-3,71)^{2}+(2,28-2,76)^{2} \\
+(2,09-2,40)^{2}+(2,26-2,49)^{2}+(1,85-2,17)^{2}
\end{array}}=2,30 \\
& d_{\text {Aceh }, c 2}=\sqrt{\begin{array}{l}
(3,13-11,33)^{2}+(2,74-10,84)^{2}+(3,66-10,52)^{2} \\
+(3,38-9,90)^{2}+(2,98-8,68)^{2}+(2,28-7,73)^{2} \\
+(2,09-7,67)^{2}+(2,26-8,48)^{2}+(1,85-7,47)^{2}
\end{array}}=19,65
\end{aligned}
$$




$$
d_{\text {Aceh, ca }}=\sqrt{\begin{array}{l}
(3,13-7,34)^{2}+(2,74-7,10)^{2}+(3,66-7,59)^{2} \\
+(3,38-7,38)^{2}+(2,98-6,44)^{2}+(2,28-5,24)^{2} \\
+(2,09-5,09)^{2}+(2,26-5,75)^{2}+(1,85-4,95)^{2}
\end{array}}=10,94
$$

Untuk melihat hasil perhitungan jarak ke setiap medoids, dapat dilihat pada tabel 3. berikut:

Tabel 3. Hasil Perhitngan Jarak ke Setiap Medoids

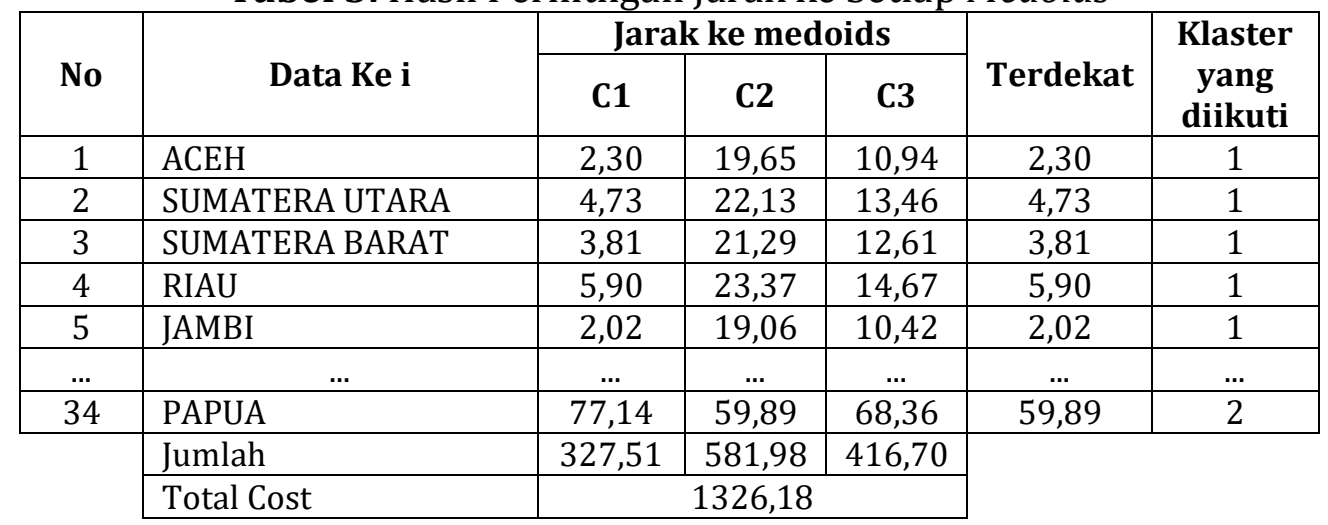

c. Mengansumsikan objek yang telah ditentukan sebagai non medoids berikut:

Tabel 4. Non Medoids

\begin{tabular}{|c|l|c|c|c|c|c|c|c|c|c|}
\hline Nama & Provinsi & $\mathbf{2 0 0 9}$ & $\mathbf{2 0 1 0}$ & $\mathbf{2 0 1 1}$ & $\mathbf{2 0 1 2}$ & $\mathbf{2 0 1 3}$ & $\mathbf{2 0 1 4}$ & $\mathbf{2 0 1 5}$ & $\mathbf{2 0 1 6}$ & $\mathbf{2 0 1 7}$ \\
\hline D1 & Gorontalo & 3,82 & 3,61 & 4,75 & 4,33 & 3,07 & 2,08 & 1,62 & 1,56 & 1,53 \\
\hline D2 & $\begin{array}{l}\text { Sulawesi } \\
\text { Barat }\end{array}$ & 10,81 & 10,09 & 11,01 & 9,69 & 8,07 & 6,83 & 6,25 & 7,25 & 6,29 \\
\hline D3 & Maluku & 2,23 & 2,21 & 3,06 & 2,62 & 1,98 & 1,12 & 1,01 & 1,06 & 0,81 \\
\hline
\end{tabular}

d. Menempatkan kembali objek-objek non medoids ke dalam cluster yang paling dekat dengan medoids berdasarkan jarak Euclidean. Berikut adalah perhitungan jarak pada data buta huruf :

$$
\begin{aligned}
& d_{\text {Aceh, }, 1}=\sqrt{\begin{array}{l}
(3,13-3,82)^{2}+(2,74-3,61)^{2}+(3,66-4,75)^{2} \\
+(3,38-4,33)^{2}+(2,98-3,07)^{2}+(2,28-2,08)^{2} \\
+(2,09-1,62)^{2}+(2,26-1,56)^{2}+(1,85-1,53)^{2}
\end{array}}=2,05 \\
& d_{\text {Aceh }, D 2}=\sqrt{\begin{array}{l}
(3,13-10,81)^{2}+(2,74-10,09)^{2}+(3,66-11,01)^{2} \\
+(3,38-9,69)^{2}+(2,98-8,07)^{2}+(2,28-6,83)^{2} \\
+(2,09-6,25)^{2}+(2,26-7,25)^{2}+(1,85-6,29)^{2}
\end{array}}=17,76 \\
& d_{\text {ACgh }, D \mathrm{a}}=\sqrt{\begin{array}{l}
(3,13-2,23)^{2}+(2,74-2,21)^{2}+(3,66-3,06)^{2} \\
+(3,38-2,62)^{2}+(2,98-1,98)^{2}+(2,28-1,12)^{2} \\
+(2,09-1,01)^{2}+(2,26-1,06)^{2}+(1,85-0,81)^{2}
\end{array}}=2,84
\end{aligned}
$$


Untuk melihat hasil perhitungan jarak ke setiap non medoids, dapat dilihat pada tabel 5. berikut:

Tabel 5. Hasil Perhitungan Jarak ke Setiap Non Medoids

\begin{tabular}{|c|l|c|c|c|c|c|}
\hline \multirow{2}{*}{ No } & \multirow{2}{*}{ Data Ke i } & \multicolumn{3}{|c|}{ Jarak ke medoids } & \multirow{2}{*}{ Terdekat } & $\begin{array}{c}\text { Klaster } \\
\text { yang } \\
\text { diikuti }\end{array}$ \\
\cline { 3 - 6 } & & $\mathbf{C 1}$ & $\mathbf{C 2}$ & $\mathbf{C 3}$ & & 1 \\
\hline 1 & Aceh & 2,05 & 17,76 & 2,84 & 2,05 & 1 \\
\hline 2 & Sumatera Utara & 3,64 & 20,19 & 0,57 & 0,57 & 3 \\
\hline 3 & Sumatera Barat & 2,65 & 19,32 & 1,07 & 1,07 & 3 \\
\hline 4 & Riau & 4,94 & 21,47 & 1,40 & 1,40 & 3 \\
\hline 5 & Jambi & 1,23 & 17,11 & 3,31 & 1,23 & 1 \\
\hline$\ldots$ & & $\ldots$ & $\ldots$ & $\ldots$ & $\ldots$ & $\ldots$ \\
\hline 34 & Papua $\quad . .$. & 78,47 & 61,90 & 81,93 & 61,90 & 2 \\
\hline & Jumlah & 327,74 & 537,90 & 359,68 & & \\
\cline { 2 - 4 } & Total Cost & \multicolumn{3}{|c|}{1225,31} \\
\hline
\end{tabular}

e. Menghitung nilai $S$ dengan persamaan sebagai berikut:

$S=$ total cost baru - total cost lama

Dengan : $S=$ Selisih

Total cost baru = total cost non medoids

Total cost lama = total cost untuk medoids

Sehingga diperoleh:

$S=1225,31-1326,18=-100,88$

f. Menukar nilai non medoids jika nilai $S<0$, sehingga D1, D2, dan D3 menjadi objek medoids.

g. Mengasumsikan objek yang telah ditentukan sebagai non medoids sebagai berikut:

Tabel 6. Non Medoids Baru

\begin{tabular}{|c|l|c|c|c|c|c|c|c|c|c|}
\hline Nama & Keterangan & $\mathbf{2 0 0 9}$ & $\mathbf{2 0 1 0}$ & $\mathbf{2 0 1 1}$ & $\mathbf{2 0 1 2}$ & $\mathbf{2 0 1 3}$ & $\mathbf{2 0 1 4}$ & $\mathbf{2 0 1 5}$ & $\mathbf{2 0 1 6}$ & $\mathbf{2 0 1 7}$ \\
\hline E1 & Maluku Utara & 3,78 & 3,48 & 3,65 & 3,12 & 2,34 & 1,54 & 1,39 & 1,33 & 1,22 \\
\hline E2 & Papua Barat & 6,40 & 4,41 & 6,99 & 4,80 & 4,31 & 3,37 & 2,83 & 2,95 & 2,62 \\
\hline E3 & Papua & 27,77 & 29,59 & 33,82 & 31,76 & 30,87 & 27,35 & 26,81 & 28,98 & 24,20 \\
\hline
\end{tabular}

h. Menempatkan kembali objek-objek non medoids ke dalam cluster yang paling dekat dengan medoids untuk mencari jarak non medoids baru. Berikut adalah perhitungan jarak pada data buta huruf :

$$
\begin{gathered}
d_{\text {Aceh }, E 1}=\sqrt{\begin{array}{l}
(3,13-3,78)^{2}+(2,74-3,48)^{2}+(3,66-3,65)^{2} \\
+(3,38-3,12)^{2}+(2,98-2,34)^{2}+(2,28-1,54)^{2} \\
+(2,09-1,39)^{2}+(2,26-1,33)^{2}+(1,85-1,22)^{2}
\end{array}}=19,94 \\
d_{\text {Aceh }, E 2}=\sqrt{\begin{array}{l}
(3,13-6,40)^{2}+(2,74-4,41)^{2}+(3,66-6,99)^{2} \\
+(3,38-4,80)^{2}+(2,98-4,31)^{2}+(2,28-3,37)^{2} \\
+(2,09-2,83)^{2}+(2,26-2,95)^{2}+(1,85-2,62)^{2}
\end{array}}=5,58
\end{gathered}
$$




$$
d_{\text {Aceh }, E \mathrm{a}}=\sqrt{\begin{array}{l}
(3,13-27,77)^{2}+(2,74-29,59)^{2}+(3,66-33,82)^{2} \\
+(3,38-31,76)^{2}+(2,98-30,87)^{2}+(2,28-27,35)^{2} \\
+(2,09-26,81)^{2}+(2,26-28,98)^{2}+(1,85-24,20)^{2}
\end{array}}=79,21
$$

Untuk melihat hasil perhitungan jarak ke setiap non medoids baru, dapat dilihat pada tabel berikut :

Tabel 7. Hasil Perhitungan Jarak ke Setiap Non Nedoids Baru

\begin{tabular}{|c|l|c|c|c|c|c|}
\hline \multirow{2}{*}{ No } & \multirow{2}{*}{ Data Ke i } & \multicolumn{3}{|c|}{ Jarak ke medoids } & \multirow{2}{*}{ Terdekat } & Klaster yang diikuti \\
\cline { 3 - 6 } & & C1 & C2 & C3 & & \\
\hline 1 & Aceh & 1,94 & 5,58 & 79,21 & 1,94 & 1 \\
\hline 2 & Sumatera Utara & 2,10 & 7,81 & 81,77 & 2,10 & 1 \\
\hline 3 & Sumatera Barat & 1,38 & 6,91 & 80,91 & 1,38 & 1 \\
\hline 4 & Riau & 3,53 & 9,09 & 82,93 & 3,53 & 1 \\
\hline 5 & Jambi & 1,37 & 4,86 & 78,76 & 1,37 & 1 \\
\hline$\ldots$ & \multicolumn{1}{c}{$\ldots$} & $\ldots$ & $\ldots$ & $\ldots$ & $\ldots$ & $\ldots$ \\
\hline 34 & Papua & 80,04 & 74,41 & 0,00 & 0,00 & 3 \\
\hline \multirow{2}{*}{ Jumlah } & 329,77 & 350,94 & 2382,86 & & \\
\cline { 2 - 4 } & Total Cost & \multicolumn{3}{|c|}{3063,56} & & \\
\cline { 2 - 3 }
\end{tabular}

i. Hitung kembali nilai $S$ sebagai berikut:

$S=3063,56-1225,31=1838,25$

j. Jika nilai $S>0$ maka proses cluster dihentikan. Sehingga diperoleh anggota tiap cluster sebagai berikut :

Tabel 8. Hasil Pengklasteran Data dengan K-Medoids Clustering

\begin{tabular}{|c|l|c|c|c|c|c|}
\hline \multirow{2}{*}{ No } & \multirow{2}{*}{ Data Ke i } & \multicolumn{3}{|c|}{ Jarak ke medoids } & \multirow{2}{*}{ Terdekat } & $\begin{array}{c}\text { Klaster } \\
\text { yang } \\
\text { diikuti }\end{array}$ \\
\cline { 3 - 6 } & & $\mathbf{C 1}$ & $\mathbf{C 2}$ & $\mathbf{C 3}$ & & 1 \\
\hline 1 & Aceh & 1,94 & 5,58 & 79,21 & 1,94 & 1 \\
\hline 2 & Sumatera Utara & 2,10 & 7,81 & 81,77 & 2,10 & 1 \\
\hline 3 & Sumatera Barat & 1,38 & 6,91 & 80,91 & 1,38 & 1 \\
\hline 4 & Riau & 3,53 & 9,09 & 82,93 & 3,53 & 1 \\
\hline 5 & Jambi & 1,37 & 4,86 & 78,76 & 1,37 & 1 \\
\hline$\ldots$ & $\ldots$ & $\ldots$ & $\ldots$ & & & \\
\hline 34 & Papua & 80,04 & 74,41 & 0,00 & 0,00 & 3 \\
\hline
\end{tabular}

Berdasarkan dari penjelasan diatas pada data yang telah dianalisa disimpulkan bahwa data yang adalah valid. Ini dibuktikan dengan hasil akhir pehitungan manual dengan hasil akhir dari aplikasi RapidMiner 5.3. dapat menampilkan hasil akhir yang sama. Berikut adalah tampilan cluster model berupa teks yang ada dalam aplikasi RapidMiner 5.3 dari cluster yang terbentuk: 


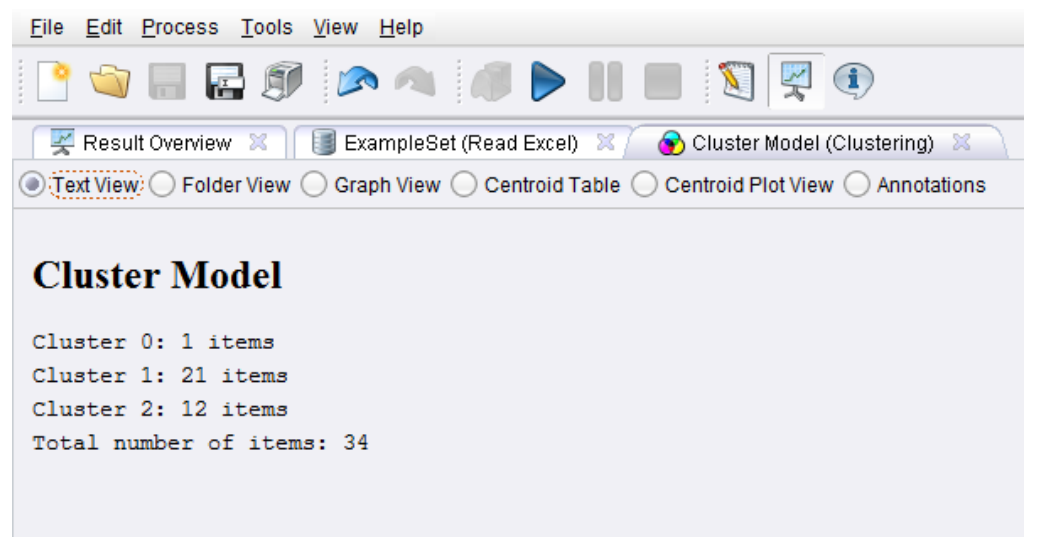

Gambar 2. Cluster Model Penduduk Buta Huruf

Selanjutnya adalah tampilan Folder view yang ada pada aplikasi RapidMiner 5.3.

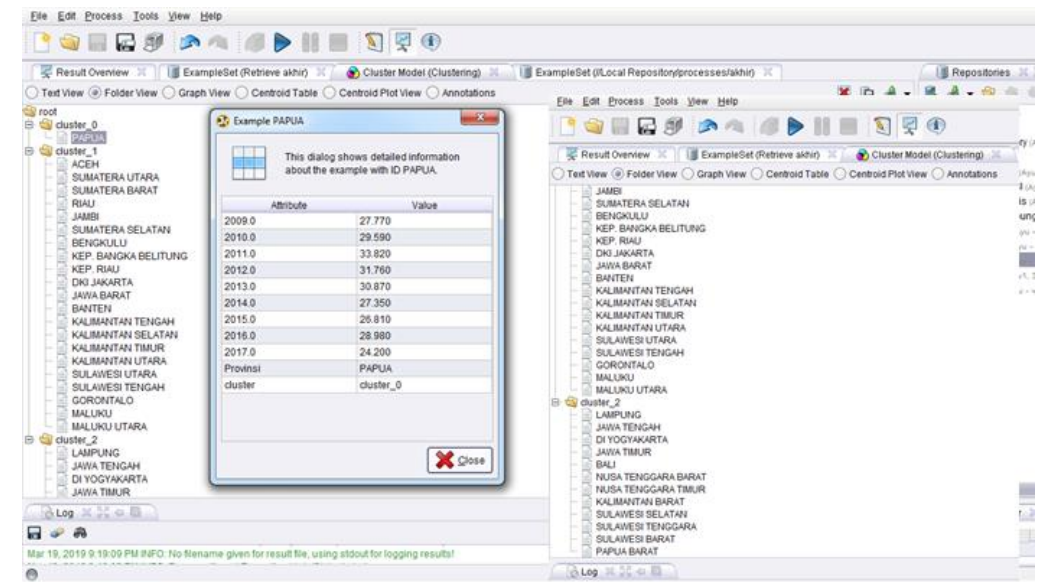

Gambar 3. Folder view Penduduk Buta Huruf

\section{KESIMPULAN}

Dari pembahasan diatas menghasilkan 3 cluster yakni cluser tinggi, cluster sedang dan cluster rendah. Dari hasil perhitungan $k$-medoids diperoreh sebanyak 1 provinsi sebagai cluster tinggi (Papua), 12 provinsi sebagai cluster sedang (Lampung, Jawa Tengah, DI Yogyakarta, Jawa Timur, Bali, Nusa Tenggara Barat, Nusa Tenggara Timur, Kalimantan Barat, Sulawesi Selatan, Sulawesi Tenggara, Sulawesi Barat, Papua Barat) dan 21 provinsi sebagai cluser rendah (Aceh, Sumatera Utara, Sumatera Barat, Riau, Jambi, Sumatera Selatan, Bengkulu, Kep. Bangka Belitung, Kep. Riau, DKI Jakarta, Jawa Barat, Banten, Kalimantan Tengah, Kalimantan Selatan, Kalimantan Timur, Kalimantan Utara, Sulawesi Utara, Sulawesi Tengah, Gorontalo, Maluku, Maluku Utara). Berdasarkan hasil pengelompokkan pada metode $k$-medoids untuk kasus penduduk buta huruf menggunakan aplikasi RapidMiner 5.3. diperoleh perhitungan yang sama dengan analisis manual yang menjadi masukkan kepada pihak pemerintah dalam upaya pemerataan tingkat buta huruf dalam menunjang kemajuan di Indonesia. Sistem 
yang digunakan hanya sebagai alat bantu untuk memberikan informasi kepada pemerintah sebagai bahan pertimbangan dalam mengambil keputusan.

\section{DAFTAR PUSTAKA}

[1] I. Parlina, A. P. Windarto, A. Wanto, and M. R. Lubis, "Memanfaatkan Algoritma K-Means Dalam Menentukan Pegawai yang Layak Mengikuti Asessment Center," CESS Journal Comput. Eng. Syst. Sci., vol. 3, no. 1, pp. 87-93, 2018.

[2] A. P. Windarto, "Implementation of Data Mining on Rice Imports by Major Country of Origin Using Algorithm Using K-Means Clustering Method," Int. J. Artif. Intell. Res., vol. 1, no. 2, pp. $26-$ 33, 2017.

[3] Sudirman, A. P. Windarto, and A. Wanto, "Data mining tools | rapidminer : K-means method on clustering of rice crops by province as efforts to stabilize food crops in Indonesia," in IOP Conference Series, 2018, pp. 1-8.

[4] N. A. Widiastuti, S. Santosa, and C. Supriyanto, "Algoritma Klasifikasi Data Mining Naïve Bayes Berbasis Particle SWARM," J. Pseudocode, vol. 1, no. 1, pp. 11-14, 2014.

[5] D. F. Pramesti, M. T. Furqon, and C. Dewi, "Implementasi Metode K-Medoids Clustering Untuk Pengelompokan Data Potensi Kebakaran Hutan / Lahan Berdasarkan Persebaran Titik Panas ( Hotspot )," J. Pengemb. Teknol. Inf. dan Ilmu Komput., vol. 1, no. 9, pp. 723-732, 2017.

[6] Z. Mustofa and I. S. Suasana, "Algoritma Clustering K-Medoids Pada E-Government Bidang Information And Communication Technology Dalam Penentuan Status EDGI," vol. 9, pp. 1-10, 2018.

[7] D. Listiyanti, Y. A. Syahbana, and S. R. Henim, "Perancangan dan Implementasi Aplikasi Android Penentu Salient Area pada Video dengan Algoritma," in ANNUAL RESEARCH SEMINAR 2016, 2016, vol. 2, no. 1, pp. 96-101.

[8] A. Y. Rofiqi, "Clustering Berita Olahraga Berbahasa Indonesia Menggunakan Metode KMedoid," J. Simantec, vol. 6, no. 1, pp. 25-32, 2017. 